ALOK MISHRA, Ph.D.

E-mail: alok@atilim.edu.tr

DEEPTI MISHRA, Ph.D.

E-mail: deepti@atilim.edu.tr

Atilim University, Department of Computer Engineering

Kızılcaşar Mahallesi, 06836 incek, Ankara,

Republic of Turkey
Transport Telematics

Review

Accepted: Oct. 14, 2009

Approved: Sept. 15, 2010

\title{
APPLICATION OF RFID IN AVIATION INDUSTRY: AN EXPLORATORY REVIEW
}

\begin{abstract}
Recently, Radio Frequency Identification (RFID) has received considerable attention and is considered to be the next wave of information technology revolution. The number of RFID applications in different industries is increasing continuously. Cumulative sales of RFID tag is up in 2006 which shows RFID adoption trend in industries to improve their efficiency of operations and to gain a competitive advantage. In the aviation industry, major airports, airlines have been also planning the RFID adoption in baggage handling and customer services areas for a long time. Many pilot tests have been performed at various airports and RFID tags were found to be far more precise along with better performance than bar codes. This paper provides a review on RFID systems, associated technology, advantages, limitations and applications in various fields. Further, this paper reports the preliminary review of state of RFID adoption planning, architecture and implementation plan in a major airline, focusing on improved baggage handling, increased airport/airline security and customer services.
\end{abstract}

\section{KEYWORDS}

aviation, airline, baggage handling, customer-service, Radio Frequency Identification (RFID)

\section{INTRODUCTION}

Radio Frequency Identification (RFID) is an emerging technology that is increasingly being used in business and industry. RFID technology provides enormous economic benefits for both business and consumers while simultaneously potentially constituting one of the most invasive surveillance technologies threatening consumer privacy [1].

Airline industry is just one of many industries that could benefit from RFID technology. In the travel industry, the pressure to provide better customer service has never been greater. Yet, the pressure to reduce the operating costs is equally strong. This is an industry which operates on average profit margins of less than $4 \%$. Airport automation can play a key role in attaining these goals, and today many innovative solutions are available to assist in this regard. According to a 2008 baggage report by SITA, the aviation industry lost 12.4 billion in 2007 as a result of mishandled baggage, reflected in the increasing passenger numbers and congestion, cost pressures and tougher security regulations, making it more difficult to track and trace bags; a concerted effort is being made with RFID to help address this and there is still hope that the technology could soon become the panacea to lost luggage [2]. In Civil aviation baggage handling application, the RFID tags are used to enhance the ability for baggage tracking, dispatching and conveyance, so as to improve the management and the customers' satisfaction.

This paper reviews RFID applications and also reports how RFID implementation will ensure effective management of baggage tracking/delivery and providing customized and personalized services to the premium customers. There have been reports of airlines and airports abandoning RFID system implementations and pilot tests due to the lack of demonstrateable return on investment but here tangible and intangible benefits like efficient baggage handling and improved services to premium customers will outweigh the costs.

The article is structured as follows: In section 2, RFID technology is described. Section 3 addresses the related work of the topic. Section 4 presents the real life RFID adoption planning and initial implementation as a case study. Finally, section 5 concludes with discussions.

\section{RFID SYSTEM}

RFID is an automatic identification technology widely used to identify, track, and detect various objects. It allows an object or person to be automatically identified at a distance using an electromagnetic exchange [3][4]. An RFID system comprises tags and a reader-writer that includes an antenna and scanner. 
The RFID tag, an electronic label attached to objects used to store data, contains a small integrated circuit chip and antenna encapsulated in a protective shell. The RFID reader-writer antenna and scanner reads/ sends data to and from RFID tags through radio frequency. The RFID system consists of five components as shown in Figure 1:

- Tag: Tags are attached with an object and contain microchips that store the unique identification (ID) of each object [5]. The ID is a serial number stored in the RFID memory [5]. RFID memory chip can be permanent or changeable depending on the read/ write characteristics [5].

- Antenna: The antennas are the conduits for the communication of data between the tag and the reader [6].

- Reader: Although named as reader, technically, the units are transceivers - a combination of transmitter and receiver. An RFID reader is a device that can read data from and write data to compatible RFID tags [6]. It reads tag data through the RFID antennas at a certain frequency [7]. All the tags in the reader range may reply at the same time, in this case the reader must detect signal collision (indication of multiple tags) [8]. The reader consists of a builtin anti-collision schemes and a single reader operating on multiple frequencies [5]. Communication between tag and reader enables the location information of an item to be recorded and transferred to the database server through the application software via a computer network thus allowing the movement of the item to be tracked and traced [6].

- Communication infrastructure: the communication infrastructure is a collection of wired or wireless network communications that transfers the data between tag and reader; and also between reader and database server through application software.

- Softwares: These include appropriate application software, database management software, middleware etc. operating in different computer systems.

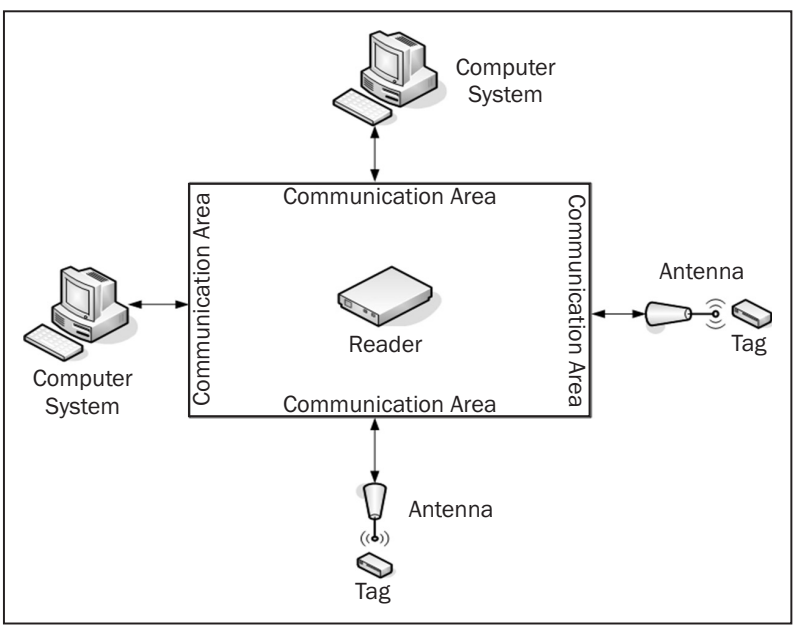

Figure 1 - A simplified view of an RFID System
RFID technology allows users to capture, store, and communicate ID information as well as detailed data on tags. RFID is a proven technology ready to be deployed to capture data efficiently, and it makes items intelligent enough to provide both basic identification information as well as relevant critical data [9].

The technology used is similar to that in bar code labelling, which uses radio waves rather than light waves to read tags [10]. RFID offers the following advantages over other well known auto-ID technologies such as the barcode [11]:

- Unique identification: Applying for instance the "Electronic Product Code" (EPC) standards, RFID tags can identify classes of products as well as individual items.

- No line of sight: RFID tags can be read without direct line of sight even if the tag is covered, dirty or otherwise obscured from view.

- Bulk reading: If they are in the reader's range, multiple RFID tags can be read at the same time.

- Storage capacity: RFID tags can store significantly more information than just an identification number.

- Dynamic information: RFID tags with read/write capability allow information to be updated or changed whenever necessary.

Additionally, RFID tags are more durable and require less maintenance than barcodes. Unfortunately, RFID is not yet a mature technology. There are still a number of issues that remain to be solved [12] such as:

- Effects of metal and liquid: Tags operating on radio frequency are not completely unaffected by materials in their close vicinity. Signals can be attenuated or detuned by metals or liquids.

- Multiple standards: In the past, several different frequencies and standards have been used for RFID solutions. Although the standardization organization EPC global has now designed a comprehensive new framework, it will take some time to establish these standards.

- Amount of data: Collection and communication of enhanced object information inevitably leads to huge amounts of data. It is unclear how this data should best be integrated into the enterprise information systems. A common approach is to endorse the ERP systems with RFID middleware. Moreover, enterprises still lack reasonable services and do not know what to do with the additional data.

Some RFID application areas are given in Table 1.

\section{RELATED WORK}

In aviation industry, major airports have been looking for the opportunities in baggage handling area since 1999 [28]. Many pilot tests regarding RFID have been done at numerous U.S. and European airports 
Table 1 - RFID applications and available literature

\begin{tabular}{|c|c|}
\hline Application area & References \\
\hline E-passport & Ezovski and Watkins, 2007 [13]; Meingast et al. 2007 [14]; Juels et al., 2005 [15] \\
\hline Health care & Tzeng et al., 2008 [16]; Venkatesan and Grauer, 2004 [17] \\
\hline Customer loyalty management & Bayraktar and Yilmaz, 2007 [18]; Capizzi and Ferguson, 2005 [19] \\
\hline $\begin{array}{l}\text { Tracking children or people } \\
\text { with special needs }\end{array}$ & Konkel et al., 2004 [20] \\
\hline Baggage handling and tracking & $\begin{array}{l}\text { DeVries, } 2008 \text { [21]; Fung et al., } 2007 \text { [22]; Viswanadham et } \\
\text { al., } 2006 \text { [23]; Wyld, Jones and Totten, 2005 [24] }\end{array}$ \\
\hline Airport security & Sample, Taylor and Rao, 2004 [25]; Feder, 2004 [26]; Cerino and Walsh, 2000 [27] \\
\hline Aircraft Maintenance & Chang et al., 2006 [28] \\
\hline Amusement park & Kelly, 2006 [29] \\
\hline Animal Detection & Artmann, 1999 [30]; Wismans, 1999 [31]; Streit et al., 2003 [32] \\
\hline Cargo & Hsu et al., 2008 [33] \\
\hline Food and beverage management & Gandino et al., 2007 [34]; Swedberg, 2006 [35]; Roberti, 2007 [36] \\
\hline RFID-tagged casino chips & Gellatly, 2005 [37] \\
\hline Hotel & Oztaysi et al., 2009 [38]; O’Connor, 2006 [39] \\
\hline Restaurant & Ngai et al., 2008 [6]; Tan and Chang, 2010 [40] \\
\hline Library & Kwok et al., 2008 [41]; Coyle, 2005 [42]; Fabbi et al., 2005 [43] \\
\hline Retailing & $\begin{array}{l}\text { Karkkainen, } 2003 \text { [44]; Jones et al., } 2004 \text { [45]; Eckfeldt, } 2005 \\
\text { [46]; Jones et al., } 2005 \text { [47]; Prater et al.,2005 [48] }\end{array}$ \\
\hline Waste management & Wager et al., 2005 [49] \\
\hline Toll collection system & Blythe, 1999 [50] \\
\hline RFID-tagged public transport cards & Hassan and Chatterjee, 2006 [51] \\
\hline Museum & Hsi and Fait, 2005 [52]; Raptis et al., 2005 [53]; Fuschi et al., 2005 [54] \\
\hline Shopping & Liao and Lin, 2007 [55]; Foroohar et al., 2004 [56] \\
\hline $\begin{array}{l}\text { Supply chain Manage- } \\
\text { ment/Logistics }\end{array}$ & $\begin{array}{l}\text { Lee et al., } 2008 \text { [57]; Kim et al. } 2008 \text { [58]; Bottani and Rizzi, } 2008 \\
\text { [59]; Hsu et al., 2008 [60]; Martinez-Sala et al. } 2009 \text { [61] }\end{array}$ \\
\hline Building management & Sommerville and Craig, 2005 [62] \\
\hline Construction & Jaseiskis and Ei-Misalami, 2003 [63]; Yagi et al., 2005 [64] \\
\hline
\end{tabular}

[28]. In the U.S. tests, RFID tags were far more accurate than bar codes when applied to baggage handling operation [28]. Nath, Reynolds and Want [65] advocates embedding RFID tags in luggage labels as it could eliminate the need for manual inspection and routing by baggage handlers. A network of readers placed along conveyor belts could read the tags' routing information and provide feedback to a system that could then direct the bags onto the correct path [65]. Automatic routing could reduce the number of misrouted bags, lowering costs and improving customer satisfaction [65]. Al-Ali et al. [66] described the design and implementation of a prototype system for baggage handling in the airport to enhance the management and tracking of passengers' luggage while as a side effect improving airport security. Wyld et al. [24] showed by specifically focusing on Delta Airlines how RFID technology can improve customer service through better operational efficiency in baggage handling, which has been demonstrated to be an integral component of an airline's customer service equation.
Even though the value of RFID-enabled technologies in handling passenger bags is generally accepted in the industry, the adoption of these technologies is hindered by concerns relating to inadequate return on investment on them [23]. Viswanadham et al. [23] argued that the reason most of the projects failed to demonstrate the needed financial return was because they focused primarily on increased labour productivity in the baggage scanning process, instead of considering other more valuable applications of RFID-enabled technologies, such as the saving in time, money and effort from the avoidance of costly baggage handling exceptions. Other issues that needs to be worked out, other than tag costs: the infrastructure and tags themselves. It is unclear who will foot the bill for installing RFID systems because the responsibility for baggage handling varies around the world. Experts recommend that it will be more beneficial if the airports rather than the individual airlines adopt the system [21]. Viswanadham et al. [23] tried to address this issue by highlighting scenarios in the baggage handling process 
where RFID-enabled technologies may be uniquely positioned to create value. The prediction is that as more airlines start to implement radio frequency technology for baggage tagging, the cost of tags and readers will drop, which in turn will likely encourage more airlines to follow suit. Some RFID applications in aviation sector are [27]:

- Passenger Baggage Sorting: The inability to obtain high read rates of barcode, once the baggage tags having barcode have experienced some measure of handling. Some RFID tag systems tested resulted in read-rates in excess of $98 \%$ for both originating and transfer baggage.

- Containers: Passenger baggage containers or universal loading devices (ULDs) are used to store many individual pieces of luggage and are loaded as a single unit. The process of sorting luggage by destination and container positioning, besides supporting minimized ground turn-around time, is important to support the security procedure of passenger bag matching and also for operational efficiency.

- Passenger/Baggage Matching: This necessitates ensuring that only boarded passengers' baggage is loaded onto the aircraft. Similarly, if a multi-flight segment passenger decides to terminate their journey prior to the final destination, the container with that person's baggage needs to be located and removed from the aircraft so as to locate and remove the passengers' baggage.

- Cargo: Large size cargo parcels would require larger read volumes and hence could render some technologies inadequate for cargo but adequate for passenger baggage. As such, only an RFID system with enough flexibility and performance features to allow achievement of cargo and passenger baggage sorting requirements would be a realistic option for most of the aviation community.

- Baggage/Cargo/Container Tracking and Locating: The application of RFID for tracking and rapid locating of baggage cargo and containers not only would be more time and labour efficient but also more accurate. It can offer the opportunity for: centralized monitoring; continuous or near-continuous surveying; automatic event logging; and more rapid finding of items when retrieval is mandatory.

- Verification/Authentication: Certain passenger's baggage is screened and considered to be cleared for loading onto the aircraft. Consequently, it is imperative that the process should be able to accurately verify that the bag in question definitely is the bag that has been deemed to be cleared for loading. Moreover, RFID baggage tags and RFID tickets provided to the passenger would allow identification/matching of the person who checked the baggage on departure with the person who retrieved the baggage upon arrival. This would virtually elimi- nate stolen luggage at arrival halls as well as providing the air carrier with logged proof in the event of the later falsified claims against the baggage delivery process.

\section{CASE STUDY}

This is a case-study of an airline which is a member of the Star Alliance group. The airline needs to maintain top level of flexibility to face new challenges from competitors around the world, and to identify and create new services to improve customer satisfaction and reduce costs.

\subsection{Weaknesses of current system}

The increase in passenger and baggage volumes, plus the development of global alliances and dual transfer flights, all create big challenges to airlines and airports. This is especially true for an airline handling over 2 billion passengers per year. This puts an extra load to the existing baggage handling system, which relies on an aging Barcode system. The airline, therefore, requires a highly efficient method to handle the increasing passenger and baggage volumes, and RFID technology has drawn the attention of the airline.

\subsection{Project goals}

One of the key priorities for the airline is to offer excellent service to its clientele and, in addition, the company appears to target mainly the premium segment of the market. The major advantage of targeting the top end segment of the market is that it gives the airlines the opportunity to maximize revenue and profit generation, a key factor in the highly competitive and not very profitable airline industry. The RFID project was started with the following objectives:

- To improve baggage tracking and delivery: To ensure better services, especially in terms of service delivery. Improvement in baggage tracking and baggage delivery has been identified as key business drivers.

- To improve security: The additional functionality of RFID allows information to be changed at different points in the airline system. This makes it possible to hold bags for security checking and release them for loading when checked, provided the RFID system is linked to the baggage reconciliation systems.

- To provide better services to premium customers: To initiate a new Frequent Flyer Program (FFP) experimental project for premium members based on RFID technology in order to provide customized and personalized services. 
- To ensure better services: RFID will be used to track passenger progress through airports, reducing the number of passengers arriving late at the gate and in doing so ensuring that planes leave on time.

\subsection{Business process analysis}

A business process refers to the business rules, strategies, and unique ways in which an organization coordinates work, information, and knowledge, as well as to how management coordinates work [67]. RFID is an emerging and innovative technology that can enable redesigning of business process in order to optimize operational efficiency and productivity. Three official surveys are written and published for three different classes of target groups: passengers, managers and stakeholders. Additionally, interviews were conducted with these target groups. These surveys and interviews helped to understand the current process, operating environment and their weaknesses. It was found that the following key systems need to be changed to accommodate RFID functionality:

- check-in systems,

- belt and tray conveyors,

- sorting systems,

- baggage screening,

- baggage reclaim,

- IT control and instrumentation technology.

\subsection{Requirement analysis}

The following issues and requirements are found to be crucial from the users' perspective:

- security / privacy policy;

- scalability, reliability, availability;

- system performance and speed;

- mobility of hardware parts;

- initial price and total ownership cost;

- self-managed system, automatic failover;

- using contactless remote-controlled cards;

- ISO-18000 compliant.

\subsection{System design}

Keeping the above facts in mind, the design of the system was produced. The users were involved in the system architecture design process indirectly, from surveys and initial interviews as well as directly via interviews and meetings throughout the designing process. The users were not directly involved in other parts like hardware and software specification. The selected technologies were chosen based on the users' requirements, their compatibility with other parts of airlines IT infrastructure and cost implications. The company selected the system which follows 'EPC global UHF Gen 2' standard protocol, the most reliable and accepted standard in implementing RFID projects. The specifications of the system are illustrated in three sections: Architecture, Hardware, and Software.

\subsubsection{System architecture}

The simplified view of the system architecture is shown in Figure 2. The system is made up of an RFID passive card which transmits radio frequency data that is collected by RFID wired reader, which in turns transmits data to a filtering system. This filtering system filters data based on the business rules and transmit it to an appropriate application which is connected to a host of database, via network. The database processes the data and sends it back to an appropriate application. This process will work in the same way for baggage tags as well as frequent flyer tags. For the baggage tag, it will ensure that the bag is directed to the correct belt while for frequent flyer tags, it will inform staff about the presence of the member.

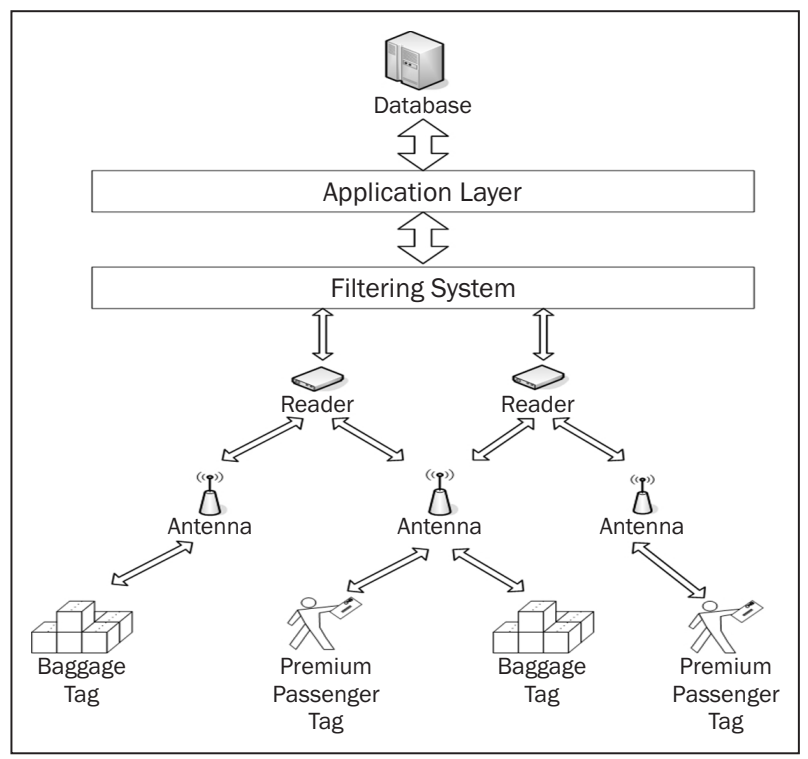

Figure 2 - Simplified view of the system architecture

The main key point of the system is a sophisticated filtering algorithm which improves the performance of the system and makes it highly scalable as well (the system works with paralleling ability, and if the number of bags or passengers increases, there will only be a need for adding another filtering system, without any drastic change in the system architecture). While the tags on the baggage will be for single-time use only, the cards for the members should theoretically be long-lasting. The system will differentiate between RFID chips for frequent flyer members and RFID luggage tags based on the data that are stored in a card and the response will be based on a set of clearly laidout business rules. 


\subsubsection{Hardware specification}

In this phase, surveys and consultants were used for making decisions besides special consideration about "Price / Total cost of ownership", and being ISO18000 compliant.

RFID tags: Tags are based on the IATA standard of RP1740c and uses $850 \mathrm{MHz}$ to $950 \mathrm{MHz}$ frequency, also known as UHF, which is licensed by different countries at different bands and powers. The air interface protocol employed is ISO-18000-6-C, which is an open standard.

RFID card: Cards are of the same size as credit cards which follow ISO-7813 with "Tag Model: 116501 GAO" which follows ISO-18000 6-C (IATA accepted standard) very low weight and is contactless with the ability of 5-500 tag read per second. As a passive tag it follows security and privacy policy regulations.

RFID reader: Fixed readers are selected due to the fact that they are used mainly for monitoring. The reader chip is 'Intel ${ }^{\circledR}$ UHF RFID Transceiver R1000 which meets EPCglobal Gen 2 and ISO 18000-6C specifications (IATA mandatory standard) and is appropriate for the purpose of the project.

Network: It is high-speed wired fibre optical LAN. The reasons for selecting this are network area, resistance to noise, highly secure and resistant to security breaches, high performance and very high speed. Although this technology is expensive, the advantages outweigh the costs. All parts of the network were wired with firewalls and all the transmitted messages are encrypted because of the security concern.

Servers: Intel Xeon $2.8 \mathrm{GHz}$ processor, Intel Xeon $3.4 \mathrm{GHz}$ processor with minimum $4 \mathrm{~GB}$ RAM and required hard disk volume based on the volume of data. These servers are used for hosting database, application server and load balancing purpose.

\subsubsection{Software specification}

Oracle application servers, with Oracle sensor edge Server as the middleware between the Oracle Database and the application. The main reason for using this technology is that the product has an approved ability of filtering data from sensor-based technology like RFID which collects unstructured data from the environment.

One of the main factors for selecting the Oracle product is that the airline is already using many Oracle products such as Oracle ERP system e-business suite; therefore, the system will be compatible. Oracle Enterprise Linux 4 Operating system is free, open source and highly compatible with Oracle products.

\subsection{System implementation}

The project will be implemented in phases based on the functionalities and logistics issues.

- Phase one: The system will be implemented for RFID baggage tags between airport where the airline is based and key airports which already have RFID capability. Premium passengers can use their RFID tags in the premium terminal at the airport where the airline is based to get more personalized service in the lounge.

- Phase two: The system will be implemented for RFID baggage tags between airport where the airline is based and high value/volume destinations. The system will use premium passengers' RFID tags for the decision-support system, analysing customer behaviour, travel trends and booking/ travelling habits of customers for better customer relationship management.

- Phase three: The system will be implemented for all destinations in the airlines network. Premium passengers can use passengers' RFID tags at all stations in the network.

\subsection{System testing and evaluation}

Testing is done at all three levels:

- Unit Testing: The system has been tested to ensure that it is error-free. This test has been done by system creator and their related team. In this stage, each part of the system is tested separately; for example, RFID readers have been tested to ensure that they work properly in real environment. Other parts of the system have been tested by following the same approach.

- System Testing: At this stage, the system has been tested as an integrated unit (testing the system as a whole). The main concept of this test is to check whether all parts of the system are compatible and work in harmony with each other. This test has been performed by special team of system architects. The penetration test has been done in this stage to check the system scalability, performance and maximum workload in which the system can operate without any problems.

- Acceptance Testing: This has been the final test and as suggested by its name, stakeholders, managers and passengers play the main roles in this stage. The main question which needs to be answered in this stage is if the system fulfils all the needs of the target groups. This has been a broad, precise test and has a documented test plan which has been written by the system developers and their clients.

For the airport tests, the focus has been on system durability, user-friendliness (stakeholders are able to work with applications easily) and whether the system users can manage other related tasks without any 
additional workload. Another focus has also been to check if there are any bugs which still exist in the system.

\section{DISCUSSION AND CONCLUSION}

RFID applications in different industries such as aviation, hospitality, supply chain logistics, manufacturing, military, health care, are increasing in number. As one of the leading airline, this airline needs to stay competitive by offering highest quality of passenger services and services level. One of the key preferences for the airline is to offer excellent service to its clientele and differentiate itself by implementing RFID technology to tag the passengers' baggage in phase one, and also the passengers themselves during later stages. The objectives of the RFID business case were cost savings and other benefits such as enhanced safety and quality control, increased customer satisfaction etc. The adoption of RFID technology for the baggage sorting and handling along with the global supply chain provides a Win-Win-Win for the three main stakeholders, the airlines, the airports and the passengers [68].

According to the survey performed by IATA [68], the RFID project is expected to offer a $9.7 \%$ saving opportunity. While barcode reading problems account for $9.7 \%$ of the total baggage mishandlings to the airline, airports deal with a much larger baggage volume. An airport requires manual interaction to ensure that the baggage makes the intended flight. If RFID technology is put into use, it allows the airport to increase the efficiency in the baggage handling operation. It is estimated as a $12.5 \%$ saving opportunity based upon an analysis of airport baggage statistics [68]. Another factor contributing to baggage mishandling is the failure to receive a baggage status message. The airline's survey results state that this factor alone will contribute to savings of around $11 \%$ [68].

While cost saving is the key business driver, there are other benefits that the RFID project can create. By implementing the latest RFID technology, it can improve the overall passenger service level by improving the tracking of mishandled baggage. The RFID technology tracks and records the baggage location when it is delivered to the wrong terminal or flight. This will enable more responsive and faster delivery of mishandled baggage.

On top of these benefits, the new technology will also enhance the speed and accuracy of baggage handling, especially when dual flight transfer is required. Passengers will be better informed, and the baggage delivery status can be tracked easily. All these functions set passengers' minds at ease and in return increase the passenger satisfaction toward the airline. With the increasing transparency of baggage handling process and a reduced baggage claiming record, the
RFID project will help the airline to build a strong brand image and set new standards of passenger service.

Furthermore, the baggage tagging initiative is also expected to reduce the overall operating cost other than the savings associated with baggage claims. With an improved efficiency in baggage handling and tracking, the reduced number of baggage claims will free customer service resources to carry out more important activities like customized services for frequent travellers. Enhanced baggage handling will improve the resources planning capability and strengthen the decision-making capabilities of the airline. The swift tracking function of the RFID system will help the airline to identify areas of failure, and can help to identify the problem caused by other carriers or airports. By feeding the information to IT tools like dashboards, it can help the airline to manage its global productivity and performance, and allow to make necessary changes and decisions efficiently and effectively.

The result and logging of performance can contribute to key service level measurement. It can assist the airline to plan for the resources allocation on one hand and become a key reference for negotiating the contract with ground handlers on the other hand.

The RFID project can improve the security management for airline and airport. After the 9/11 incident, FAA imposed great pressure on airlines to ensure proper baggage/passenger matching. This in return increased the requirement of tracking and visibility for all luggage. The airline can add different security levels into the baggage tag, together with the tracking mechanism; any misplaced bag can be identified and located immediately. The system and information logged could become key references for security audit. The overall transparency of information can help both the airlines and the airports to enhance and optimize the baggage handling process. The result and logging of performance can contribute to the key service level measurement.

After the successful implementation of the RFID baggage tagging system, the next phase of the project will be to extend the system to passenger tagging. By tracking the location of passengers with the RFID cards, customized services can be offered to increase the customer satisfaction and create a positive impact on the sales turnover. Through reading the information on the RFID embedded card of the premium passengers, they can be greeted in the language they prefer, and they can be offered their favourite newspaper and drinks once they enter the premium passenger lounge. This RFID cards can also be tracking devices to help the airlines better understand their passengers' profiles. By tracking which duty-free shops passengers visit, which restaurants they prefer etc., the cards can be a source of information for the customer relationship management system, which in turn can allow for custom-made programs to enhance business perfor- 
mance and improve customer loyalty. The efficacy of RFID not only depends on the technology itself, but also largely on the airport's ability to use the IATA standard, to recognize how the solution can work best to suit their own operational needs and through strong collaboration with RFID providers and airlines [2].

\section{Acknowledgement}

Authors would like to thank the editors and three reviewers for their insightful comments to improve the quality of the paper.

ALOK MISHRA, Ph.D.

E-mail: alok@atilim.edu.tr

DEEPTI MISHRA, Ph.D.

E-mail: deepti@atilim.edu.tr

Atilim University, Department of Computer Engineering

Kızılcaşar Mahallesi, 06836 incek, Ankara,

Republic of Turkey

\section{ÖZ}

\section{HAVACILIK SANAYISINDE RFID'NIN UYGULANMASI: KEŞIF INCELEMESI}

Son zamanlarda, Radyo Frekansı ile Tanımlama (RFID) bilgi teknoloji devriminin yeni dalgası olarak görülmekte ve çok dikkat çekmektedir. RFID uygulamaları farklı sektörlerde sürekli olarak artmaktadır. RFID etiketi kümülatif satışlarının 2006 yılında yüksek olması sektörlerin operasyonlarının verimliliğini arttırmak ve daha rekabetçi avantaj elde etmek için RFID benimseme eğiliminde olduklarını göstermektedir.

Havacılık Sanayisinde, büyük havaalanları, havayolu şirketleri uzun bir suredir bagaj taşıma ve müşteri hizmetleri alanlarında RFID'yi kabul edilecek şekilde planlanmaktadır.

Çeşitli havaalanlarında birçok pilot test gerçekleştirilmiş olup; RFID etiketlerinin bar kodlara göre daha iyi performans gösterdikleri ve daha kesin oldukları saptanmıştır. Bu makale RFID Sistemleri, ilgili teknolojiler, avantajları, kısıtları ve çeşitli alanlardaki uygulamaları üzerine bir incelemedir. Ayrıca, bu makale gelişmiş bagaj taşıma, yüksek havaalanı/ hava yolu şirketi güvenliği ve müşteri hizmetleri konularına odaklanarak RFID kabul planlama durumu ön incelemesini ve büyük havayolu şirketlerinde mimari ve uygulama planını rapor etmektedir.

\section{ANAHTAR SÖZCÜKLER}

Havacılık, havayolu, bagaj taşıma, müşteri hizmetleri, Radyo Frekansı ile Tanımlama (RFID)

\section{REFERENCES}

[1] Kelly, Eileen P., Erickson, G. Scott: RFID tags: commercial applications v. privacy rights, Industrial Management \& Data Systems, vol. 105, No. 6, 2005, 703-713.

[2] Airport-business.com: Making RFID work - the most effective solution to lost baggage? Available at http:// www.airport-business.com/2009/03/making-rfidwork-the-most-effective-solution-to-lost-baggage/
[3] Finkenzeller, K. (2003). RFID handbook: Fundamentals and applications in contactless smart cards and identification. Chichester: Wiley.

[4] Want, R. (2004). The magic of RFID. Queue, 2(7), 40-48.

[5] Ahsan K., Shah H., Kingston P., RFID Applications: An Introductory and Exploratory Study, International Journal of Computer Science Issues, Volume 7, Issue 1, No 3, pp 1-7, January 2010

[6] E.W.T. Ngai, F.F.C. Suk and S.Y.Y. Lo 2008, Development of an RFID-based sushi management system: The case of a conveyor-belt sushi restaurant. International Journal of Production Economics. Vol. 112, Issue 2, 630-645.

[7] T. Frank, H. Brad, M. Anand, B. Hersh, C. Anita, K. John, "RFID Security", (2006) ISBN: 1-59749-047-4

[8] L. Srivastava, RFID: Technology, Applications and Policy Implications, Presentation, International Telecommunication Union, Kenya, (2005).

[9] Cheng, M-Y, Tsai, H-C, Lien, Li-Chuan, Hung Kuo: GOS based restoration system for historic timber buildings using RFID technology, Journal of Civil Engineering \& Management, 14(4), 2008, 227-234

[10] Cheng, M. Y., Chen, J. C.: Integrating barcode and GIS for monitoring construction progress, Automation in Construction, 11(1), 2002, 23-33

[11] Agarwal, V. (2001). Assessing the benefits of autoID technology in the consumer goods industry. Cambridge: Cambridge Auto-ID Lab.

[12] Leimeister, S., Leimeister, J.M., Knebel, U., Krcmar, H., A cross-national comparison of perceived strategic importance of RFID for CIOs in Germany and Italy, International Journal of Information Management, Volume 29, Issue 1, February 2009, Pages 37-47

[13] G. Matthew Ezovski and Steve E. Watkins, "The Electronic Passport and the Future of Government-Issued RFID-Based Identification," in IEEE Intl Conference on RFID, pp. 15-22. March 26-28, 2007

[14] Marci Meingast, Jennifer King, Deirdre K. Mulligan, "Embedded RFID and Everyday Things: A Case Study of the Security and Privacy Risks of the U.S. e-Passport," in IEEE International Conference on RFID, pp. 7-14. March 26-28, 2007

[15] Juels, A., Molnar, D., and Wagner, D. 2005. Security and Privacy Issues in E-passports. In Proceedings of the First international Conference on Security and Privacy For Emerging Areas in Communications Networks (September 05 - 09, 2005). SECURECOMM. IEEE Computer Society, Washington, DC, 74-88

[16] TZENG S-F, CHEN W-H and PAI F-Y (2008) Evaluating the business value of RFID: evidence from five case studies. International Journal of Production Economics 112(2), 601-613

[17] Venkatesan, M., Grauer, Z., 2004. Leveraging radio frequency identification (RFID) technology to improve laboratory information management. American Laboratory 36 (18), 11-14

[18] Bayraktar, A. Yilmaz, E., Implementation of RFID Technology for the Differentiation of Loyalty Programs, $1^{\text {st }}$ Annual RFID Eurasia 2007, 1-6

[19] Capizzi, M.T., Ferguson, R., 2005. Loyalty trends for the twenty-first century. Journal of Consumer Marketing $22,72-80$ 
[20] Konkel, M., Leung, V., Ullmer, B., Hu, C., 2004. Tagaboo: a collaborative children's game based upon wearable RFID technology. Personal and Ubiquitous Computing 8, 382-384

[21] DeVries, Peter D., The state of RFID for effective baggage tracking in the airline industry, International Journal of Mobile Communications, Vol. 6, No.2, 2008, pp. 151 - 164

[22] Fung, L.C., Chan, K.H., Lam, W.K., Leung, S.W., Wong, Y.F., WuPaul, W.K., Tang, C.K., 2007. Electromagnetic assessment on human safety of RFID system at Hong Kong international airport. Microwave and Optical Technology Letters 49, 924-927

[23] Viswanadham, N., Prakasam, A., Gaonkar, R.: Decision support system for exception management in RFID enabled airline baggage handling process, Automation Science and Engineering, 2006. IEEE International Conference on, CASE '06, 8-10 Oct. 2006, 351-356

[24] Wyld, David C., Jones, Michael A., Totten, Jeffrey W.: Where is my suitcase? RFID and airline customer service, Marketing Intelligence \& Planning, Volume 23, Issue 4, 2005, 382 - 394

[25] Sample, K.B., Taylor, D.K., Rao, E.: High tech aviation security program in Africa - a model for technology transfer, Security Technology, 2004. 38th Annual 2004 International Carnahan Conference on, 11-14 Oct. 2004, 270- 277

[26] Feder, B.J., 2004. Delta to invest in radio tags for luggage at airports. New York Times, July 1, 2004, p. 5

[27] Cerino, A., Walsh, W.P., 2000. Research and application of radio frequency identification (RFID) technology to enhance aviation security. In: Proceedings of the IEEE 2000 National Aerospace and Electronics Conference, pp. 127-135

[28] Chang, Y.S., Oh, C.H., Whang, Y.S., Lee, J.J., Kwon, J.A., Kang, M.S., Park, J.S., Ung, Y.P.: Development of RFID Enabled Aircraft Maintenance System, Industrial Informatics, 2006 IEEE International Conference on, 16-18 Aug. 2006, 224-229

[29] Kelly, L., 2006. Alton Towers visitors set for RFID ride, available at http://www.computing.co.uk/computing/news/2152579/alton-towers-visitors-set-rfidS (retrieved on 15 July 2010)

[30] Artmann, R., 1999. Electronic identification systems: State of the art and their further development. Computers and Electronics in Agriculture 24 (1-2), 5-26

[31] Wismans, W.M.G., 1999. Identification and registration of animals in the European Union. Computers and Electronics in Agriculture 24 (1\&2), 99-108

[32] Streit, S., Bock, F., Pirk, C.W.W., Tautz, J., 2003. Automatic lifelong monitoring of individual insect behaviour now possible. Zoology 106 (3), 169-171

[33] Hsu, C., Shih, H., and Wang, W. 2009. Applying RFID to reduce delay in import cargo customs clearance process. Comput. Ind. Eng. 57, 2 (Sep. 2009), 506-519

[34] GANDINO F, MONTRUCCHIO B, REBAUDENGO $M$ and SANCHEZ ER (2007) Analysis of an RFID-based in formation system for tracking and tracing in an agrifood chain. In Proceedings of 1st Annual RFID Eurasia (MONTRUCCHIO B, Ed), September, pp. 1-6, Istanbul, Turkey
[35] Swedberg, C., 2006. Vegas hotel-casino uses tags to keep tabs on liquor. RFID Journal, available at http:// www.rfidjournal.com/article/articleview/2447/1/1/S (accessed on 15.07.2010)

[36] Roberti,M., 2007. RFID on tap. RFID Journal, available at http://www.rfidjournal.com/article/ articleview/2125/1/335/S (accessed on 15.07.2010).

[37] Gellatly, A., 2005. When the chips are down. Financial Times, April 20, 2005

[38] Basar Oztaysi, Serdar Baysan, and Fatma Akpinar. Radio frequency identification (rfid) in hospitality. Technovation, 29(9):618-624, 2009

[39] O'Connor, M.C., 2006. Great Wolf Water Park launches RFID. RFID Journal, March 22, 2006

[40] Tan, T. and Chang, C. 2010. Development and evaluation of an RFID-based e-restaurant system for customer-centric service. Expert Syst. Appl. 37, 9 (Sep. 2010), 6482-6492

[41] S.K. Kwok, C.F. Cheung, W.B. Lee, Albert H.C. Tsang, M.C. Tang, "Development of an RFID-enabled mobile smart library system", International Journal of Enterprise Network Management, Volume 2, Number 2 , 2008, 185 - 197

[42] Coyle, K., 2005. Management of RFID in libraries. The Journal of Academic Librarianship 31 (5), 486-489

[43] Fabbi, J.L., Watson, S.D., Marks, K.E., Sylvis, Z., 2005. UNLV libraries and the digital identification frontier. Library Hi Tech 23 (3), 313-322

[44] Karkkainen, M., 2003. Increasing efficiency in the supply chain for short shelf life goods using RFID tagging. International Journal of Retail \& Distribution Management 31 (10), 529-536

[45] Jones, P., Clarke-Hill, C., Comfort, D., Hillier, D., Shears, P., 2004. Radio frequency identification in retailing and privacy and public policy issues. Management Research News 27 (8/9), 46-56

[46] Eckfeldt, B., 2005. What does RFID do for the consumer? Communications of the ACM 48 (9), 77-79

[47] Jones, P., Clarke-Hill, C., Hillier, D., Comfort, D., 2005. The benefits, challenges and impacts of radio frequency identification technology (RFID) for retailers in the UK. Marketing Intelligence \& Planning 23 (4), 395-402

[48] Prater, E., Frazier, G.V., Reyes, P.M., 2005. Future impacts of RFID on e-supply chains in grocery retailing. Supply Chain Management: An International Journal 10 (2), 134-142

[49] Wager, P.A., Eugster, M., Hilty, L.M., Som, C., 2005. Smart labels in municipal solid waste-a case for the precautionary principle? Environmental Impact Assessment Review 25 (5), 567-586

[50] Blythe, P., 1999. RFID for road tolling, road-use pricing and vehicle access control. In: Proceedings of the IEE Colloquium on RFID Technology, vol. 123, pp. 8/1-8/ 16

[51] Hassan, T., Chatterjee, S., 2006. A taxonomy for RFID. In: Proceedings of the 39th Annual Hawaii International Conference on System Sciences, p. 184

[52] Hsi, S., Fait, H., 2005. RFID enhances visitors' museum experience at the exploratorium. Communications of the ACM 48 (9), 60-65

[53] Raptis, D., Tselios, N., Avouris, N., 2005. Contextbased design of mobile applications for museums: A 
survey of existing practices. In: Proceedings of the Mobile HCl'05 Conference, pp. 153-160

[54] Fuschi, D.L., Bo, G., Saadia, Y., 2005. Innovative applications for content distribution and consumption in tourism and education using PDA or mobiles. In: Proceedings of the First International Conference on Automated Production of Cross Media Content for MultiChannel Distribution

[55] I.-E. Liao, and W.-C. Lin, "Shopping Path Analysis and Transaction Mining Based on RFID Technology," $1^{\text {st }} \mathrm{An}$ nual RFID Eurasia, 2007

[56] Foroohar, R., Adams, J., Itoi, K., 2004. The future of shopping. Newsweek International, June 7, 2004

[57] Lorraine S. Lee, Kirk D. Fiedler, Jeffery S. Smith, Radio frequency identification (RFID) implementation in the service sector: A customer-facing diffusion model, International Journal of Production Economics, Volume 112, Issue 2, Special Section on RFID: Technology, Applications, and Impact on Business Operations, April 2008, Pages 587-600

[58] Changsu Kim, Kyung Hoon Yang, Jaekyung Kim, A strategy for third-party logistics systems: A case analysis using the blue ocean strategy, Omega, Volume 36, Issue 4, Special Issue on Logistics: New Perspectives and Challenges, August 2008, Pages 522-534

[59] Eleonora Bottani and Antonio Rizzi. Economical assessment of the impact of rfid technology and epc system on the fast-moving consumer goods supply chain. International Journal of Production Economics, 112(2):548-569, 2008

[60] Yu-Chia Hsu, An-Pin Chen, and Chun-Hung Wang. A rfid-enabled traceability system for the supply chain of live fish. In IEEE International Conference on Automa- tion and Logistics, ICAL 2008, September 1 - September 3, pages 81-86, 2008

[61] Alejandro Martinez-Sala, Esteban Egea-Lopez, Felipe Garcia-Sanchez, and Joan Garcia-Haro. Tracking of returnable packaging and transport units with active rfid in the grocery supply chain. Computers in Industry, 60(3):161-171, 2009

[62] Sommerville, J., Craig, N., 2005. Intelligent buildings with radio frequency identification devices. Structural Survey 23 (4), 282-290

[63] Jaseiskis, E.J., Ei-Misalami, T., 2003. Implementing radio frequency identification in the construction process. Journal of Construction Engineering \& Management 129 (6), 680-688

[64] Yagi, J., Arai, E., Arai, T., 2005. Parts and packets unification radio frequency identification (RFID) application for construction. Automation in Construction 14 (4), 477-490

[65] Nath, B., Reynolds, F., and Want, R.: RFID Technology and Applications. IEEE Pervasive Computing 5, 1 (Jan. 2006), 22. DOI= http://dx.doi.org/10.1109/ MPRV.2006.13

[66] Al-Ali, A.S.A., Sajwani, F., Al-Muhairi, A., Shahenn, E.: Assessing the Feasibility of Using RFID Technology in Airports, RFID Eurasia, 2007 1st Annual, 5-6 Sept. 2007, 1-5

[67] Laudon, K.C., Laudon, J.P., 1998. Management Information Systems: New Approaches to Organization and Technology. Prentice-Hall, Englewood Cliffs, NJ.

[68] IATA: RFID BUSINESS CASE FOR BAGGAGE TAGGING, 2007, available at http://www.iata.org/whatwedo/ stb/Documents/RFID\%20for\%20baggage\%20business $\% 20$ case $\% 202 \% 201 . p d f$ 